\title{
Evolution of the Deep and Bottom Waters of the Scotia Sea, Southern Ocean, during 1995-2005
}

\author{
Michael P. Meredith ${ }^{1 *}$, Alberto C. Naveira Garabato ${ }^{2}$, \\ Arnold L. Gordon ${ }^{3}$, Gregory C. Johnson ${ }^{4}$
}

${ }^{1}$ British Antarctic Survey, Cambridge, U.K.

${ }^{2}$ National Oceanography Centre, Southampton, U.K.

${ }^{3}$ Lamont-Doherty Earth Observatory of Columbia University, Palisades, New York, U.S.A.

${ }^{4}$ NOAA/Pacific Marine Environmental Laboratory, Seattle, Washington, U.S.A.

*corresponding author: $\underline{\mathrm{mmm} @ \text { bas.ac.uk }}$ 


\begin{abstract}
The Southern Ocean hosts the formation of the densest layers of the oceanic overturning circulation, and provides a climatically sensitive element of deep ocean ventilation. An oceanographic section across the eastern Scotia Sea occupied in 1995, 1999 and 2005 reveals significant variability in the deep and bottom waters of Southern Ocean origin. Warming $\left(\sim 0.1^{\circ} \mathrm{C}\right)$ of the warm mid-layer waters in the Scotia Sea between 1995 and 1999 reversed through to 2005, reflecting changes seen earlier upstream in the Weddell Sea. The volume of deep waters with potential temperature less than $0^{\circ} \mathrm{C}$ decreased during $1995-2005$, though such a reduction was only clear between 1995 and 1999 at the southern end of the section. The abyssal waters of the eastern Scotia Sea apparently changed circulation between 1995 and 1999, with the dominant point of their entry to the basin shifting from the south to the northeast; by 2005 , the former route had regained dominance. These changes are best explained by interannual variations in the deep waters exiting the Weddell Sea, superimposed on a longer-term (decadal) warming trend. The interannual variations are related to changes in the strength of the Weddell Gyre, reflecting large-scale atmospheric variability that may include the El Niño / Southern Oscillation phenomenon. The Scotia Sea is the most direct pathway for dense waters of the overturning circulation emanating from the Weddell Sea to fill much of the world ocean abyss. The regional changes reported here have the potential to affect the climatically significant ventilation of the global ocean abyss.
\end{abstract}




\section{Introduction}

Immediately east of Drake Passage, the Scotia Sea is a basin with rough bottom topography, and is separated from the Weddell Sea to the south by the South Scotia Ridge (Figure 1). The horizontal zonation of water masses in the Scotia Sea is dominated by the Antarctic Circumpolar Current (ACC) (Orsi et al., 1995). This current has a banded structure, with the main fronts being (north-tosouth) the SubAntarctic Front, Polar Front, and Southern ACC Front. The southern limit of the ACC is marked by the Southern Boundary, south of which are found the waters of the WeddellScotia Confluence. These are characterised by low vertical gradients at mid-depths due to the injection of dense waters that spill off the shelf close to the tip of the Antarctic Peninsula (Whitworth et al., 1994).

The Scotia Sea receives waters from both Drake Passage, via the ACC, and the Weddell Sea, via the northern limb of the Weddell Gyre. Water masses of Weddell Sea origin include Warm Deep Water (WDW; Table 1), characterised by a potential temperature $(\Theta)$ maximum near $500 \mathrm{~m}$ and a salinity (S) maximum near $800 \mathrm{~m}$. WDW is derived from the Circumpolar Deep Water (CDW) of the ACC that is entrained into the eastern limb of the Weddell Gyre (Orsi et al., 1993), and thereafter advected cyclonically within the Gyre.

Waters of Weddell Sea origin also include Weddell Sea Deep Water (WSDW; Table 1), the densest water mass found in the Scotia Sea. WSDW is an essential component of the Antarctic Bottom Water (AABW) that forms the abyssal layer of much of the world's oceans. WSDW is formed by the mixing of dense shelf waters with variants of WDW on the shelves and slopes of the western and southwestern Weddell Sea (Foster and Carmack, 1976; Gill, 1973; Gordon, 1998). Different 
types of WSDW are found in the Weddell Sea reflecting distinct formation processes and regions. The outer rim of the gyre features relatively fresh and oxygen-rich WSDW compared with that found closer to the centre of the gyre. The enhanced ventilation is due to injection of relatively fresh shelf water found near the northern end of the Antarctic Peninsula (Gordon et al., 2001). WSDW is underlain in the Weddell Sea by the denser Weddell Sea Bottom Water (WSBW; Table 1), which forms via similar processes to WSDW but contains a higher proportion of dense shelf waters. WSBW is too dense to escape the Weddell Sea directly, and must first mix upwards into the WSDW density class. Within the Weddell Sea, WSDW can also incorporate recently ventilated deep waters imported from the Indian Ocean sector to the east (Meredith et al., 2000).

The Scotia Sea (Figure 1) is the most direct route for WSDW to flow northward and contribute to the global overturning circulation (Locarnini et al., 1993). WSDW can enter the Scotia Sea via deep gaps in the South Scotia Ridge, of which the $~ 3200$-m deep Orkney Passage is the deepest (Gordon et al., 2001; Naveira Garabato et al., 2002b), or via gaps in the South Sandwich Island arc (Meredith et al., 2001; Naveira Garabato et al., 2002a). The northward flow of WSDW on the western edge of the Orkney Passage derives from the more ventilated form of WSDW (Gordon et al., 2001). Upon entering the Scotia Sea, WSDW can spread westward toward Drake Passage, however there is little or no net flow of this water mass through the narrowest part of the Passage into the Pacific Ocean (Gordon, 1966; Sievers and Nowlin, 1984; Nowlin and Zenk, 1988). WSDW exits the Scotia Sea primarily in the vicinity of the $~ 3200$-m deep Georgia Passage, southeast of South Georgia (Figure 1).

Upon leaving the Scotia Sea, WSDW spreads northwards into the Georgia Basin, whence it can continue northward into the Argentine Basin or recirculate southeastward back toward the Weddell 
Sea. Conventionally, WSDW is divided into Upper and Lower components in this region (Table 1) (Arhan et al., 1999; Meredith et al., 2001). The division between Upper and Lower WSDW (established by Arhan et al. (1999) and used here) is such that Upper WSDW is able to flow through the Scotia Sea to reach the Georgia Basin, whereas Lower WSDW is topographically constrained to enter the Georgia Basin via the eastern side of the South Sandwich Islands (Figure 1). The direction of abyssal Lower WSDW flow at Georgia Passage was inferred to have reversed between 1995 and 1999, with the flow being northeastward out of the Scotia Sea prior to 1995, but then changing to be southwestward into the Scotia Sea (Meredith et al., 2001).

Various changes have been reported in the properties of water masses originating from the Weddell Sea. Analysis of a long compilation of hydrographic data revealed that the coldest WDW was associated with the Weddell Polynya years of the 1970s (Robertson et al., 2002). Subsequently, this water mass warmed at a rate of around $0.012( \pm 0.007){ }^{\circ} \mathrm{C} \mathrm{yr}^{-1}$ up to the 1990 s. This warming was not compensated by a salinity increase, with the WDW becoming less dense as a result. The Scotia Sea exhibited a warming of WDW of around $0.1-0.2^{\circ} \mathrm{C}$ between 1995 and 1999, as changes originating in the Weddell Sea arrived (Meredith et al., 2001), however more recent data from close to the Greenwich Meridian in the Weddell Sea revealed a cooling of around $0.05^{\circ} \mathrm{C}$ between 1998 and 2003 after the end of the warming signal (Fahrbach et al., 2004). Tentative explanations for these changes include a change in CDW properties in the ACC (e.g. Gille, 2002) combined with variations in the rate of inflow of this water to the Weddell Gyre.

Weddell Sea temperature profiles suggest warmer WSDW between 1500 and $3500 \mathrm{~m}$ in the 1990s compared with the 1970s (Robertson et al., 2002). However, high variability in the data prevented identification of a well-defined trend. Relatively little change in WSDW properties in the Weddell 
Sea was evident during 1990 - 2003, with variations being close to the detection level (Fahrbach et al., 2004). The areas from which data were collected for that study are, however, likely to emphasise basin-wide bulk changes in properties rather than changes in the recently-ventilated forms of WSDW in the boundary currents at the periphery of the sea. The comparative stability of WSDW properties contrasts with the continuous warming (by $\sim 0.025^{\circ} \mathrm{C}$ ) experienced by WSBW between 1989 and 2003 (Fahrbach et al., 2004).

Temperature changes in the bottom waters spreading northward in the Atlantic Ocean from the Weddell Sea are apparent all the way to the equator. Directly downstream from the Scotia Sea, in the Argentine Basin, a comparison of hydrographic data collected in 1989 to data from 1980-87 showed that the coldest abyssal layer warmed significantly in that interval (Coles et al., 1996). Also in the Argentine Basin, comparison of 2005 and 1989 hydrographic section data revealed a further $\sim 0.05{ }^{\circ} \mathrm{C}$ warming of the abyssal layer (Johnson and Doney, 2006). In the Vema Channel, the deepest conduit between the Argentine Basin and the Brazil Basin to the north, the coldest bottom waters have warmed by as much as $2.8 \times 10^{-3}{ }^{\circ} \mathrm{C} \mathrm{yr}^{-1}$ from 1991 through to 2006 , after being relatively stable from 1972 to 1991 (Zenk and Morozov, 2007). In the Brazil Basin, the abyssal layers warmed by $\sim 0.04{ }^{\circ} \mathrm{C}$ between 1989 and 2005 (Johnson and Doney, 2006). Finally, at the equator, bottom $\Theta$ values increased by nearly $0.1^{\circ} \mathrm{C}$ between 1993 and 1999 (Andrié et al., 2003). These changes relate to abyssal temperatures, and whilst it is important to note that there are differences in bottom temperatures and lateral bottom temperature gradients between each of these locations, the order of magnitude and timing of the changes are suggestive of a decadal warming trend propagating northward in the South Atlantic. 
In this paper, we use repeat hydrographic data to examine the evolution of the water mass properties and circulation of Weddell Sea-derived waters in the eastern Scotia Sea over a recent decade (1995 -2005), and investigate the causes of the observed changes. Given these waters' fundamental contribution to the deepest layers of the global overturning circulation, it is important to monitor and ultimately identify the causes of their variability.

\section{Methods}

Hydrographic data were collected from three cruises in the eastern Scotia Sea that occupied virtually identical tracks (Figure 2). Each of these ran northward from the South Scotia Ridge along $\sim 31^{\circ} \mathrm{W}$, then diverted at $\sim 58^{\circ} \mathrm{S}$ toward the island of South Georgia (Figure 1). The first section was

conducted in April 1995 from the British Antarctic Survey vessel RRS James Clark Ross, and was a component of the World Ocean Circulation Experiment (WOCE) A23 section (Heywood and King, 2002). The second section was conducted from the same vessel in April 1999 (Naveira Garabato et al., 2002a), and the third was conducted in January 2005 from the NOAA ship Ronald H. Brown, as part of the U.S. CLIVAR/CO 2 Repeat Hydrography Program (Johnson and Doney, 2006).

Meredith et al. (2001) described the methods and data for the first two of these sections in detail. To summarise, the 1995 data were collected with a Neil Brown MKIIIb conductivity-temperaturedepth (CTD) profiler, with S data being calibrated relative to IAPSO P-series standard seawater using bottle salts collected with a 24-bottle rosette. The accuracy of this data is $0.001^{\circ} \mathrm{C}$ for $\Theta$ and 0.002 for S. The 1999 data were collected and calibrated in the same manner but using a Neil Brown MKIIIc CTD, with comparable accuracies achieved. The 2005 data were collected using a SeaBird Electronics (SBE) 9plus CTD fitted with SBE3 temperature sensors and SBE4 conductivity 
sensors, and with discrete samples obtained using a 36-position rosette. The accuracy of the $\Theta$ and $\mathrm{S}$ data from 2005 are $0.001^{\circ} \mathrm{C}$ and 0.002 or better, respectively (Johnson and Doney, 2006).

\section{Zonation and water masses}

Vertical sections of $\Theta, S$ and neutral density $\left(\gamma^{n}\right)$ are presented in Figures 3-5 respectively for each of the years. The major feature of horizontal zonation along this line is the Southern Boundary, found at $\sim 58.5^{\circ} \mathrm{S}$ on the 1995 section, $\sim 59^{\circ} \mathrm{S}$ on the 1999 section, and between 58.5 and $59^{\circ} \mathrm{S}$ on the 2005 section. Narrow eddy-like features containing water from south of the Southern Boundary are seen in the 1995 and 1999 sections at stations 45 and 111 (around $57^{\circ} \mathrm{S}$ and $57.5^{\circ} \mathrm{S}$ respectively) (Meredith et al., 2001). The Southern ACC Front is present at the northern end of the sections, close to stations 50, 118 and 101 in 1995, 1999 and 2005, respectively.

North of the Southern Boundary, the sections are occupied by the ACC's poleward flank, in which vertical $\Theta$ and $\mathrm{S}$ maxima indicate the cores of the upper and lower components of the CDW (Figures 3 and 4, respectively). South of the Southern Boundary lies the Weddell-Scotia Confluence; this features WDW centred around $500 \mathrm{~m}$, identifiable as the vertical $\Theta$ maximum (Figure 3). WDW of $\gamma^{\mathrm{n}}<28.20 \mathrm{~kg} \mathrm{~m}^{-3}$ is constrained to lie south of the Southern Boundary, except for its presence in the narrow eddy-like features noted above. A denser form of WDW is observed farther north at greater depths $(>500 \mathrm{~m})$, and has its origins in the modification of Southeast Pacific Deep Water by mixing with Weddell deep waters (Naveira Garabato et al., 2002a). Beneath the WDW and CDW on the section lies WSDW, here defined as waters of $\gamma^{\mathrm{n}}>28.26 \mathrm{~kg} \mathrm{~m}^{-3}$ (Figure 5). This layer resides below $\sim 1800 \mathrm{~m}$ at the southern end of the section, thins northwards, and disappears at around $55.5-56^{\circ} \mathrm{S}$. 


\section{Variability in water mass properties and circulation}

\subsection{Warm Deep Water variability}

The WDW layer south of the Southern Boundary exhibits substantial variability in $\Theta$ and S measured during the three cruises (Figure 6). In 1995, the peak WDW $\Theta$ value encountered was close to $0.41^{\circ} \mathrm{C}$, with the majority of stations showing WDW core $\Theta$ values of $0.35-0.40^{\circ} \mathrm{C}$. In the 1999 occupation of the section, the WDW core $\Theta$ values were all much higher than this, from 0.50 $-0.65^{\circ} \mathrm{C}$. In the 2005 section, the WDW core $\Theta$ had decreased again, with values below $0.45^{\circ} \mathrm{C}$. These changes are reflected in WDW maximum S values also, which increased by $\sim 0.004$ between 1995 and 1999, before decreasing by a similar amount through to 2005 (Figure 6). Note that there are some changes in the lateral position of the Southern Boundary in the sections (e.g. Figure 3), however our comparison considers only the waters south of this feature for each of the years, thus the changes we see cannot be due to such movements.

\subsection{Weddell Sea Deep Water}

Vertical sections of $\gamma^{\mathrm{n}}$ (Figure 5) indicate that the volume of WSDW $\left(\gamma^{\mathrm{n}}>28.26 \mathrm{~kg} \mathrm{~m}^{-3}\right)$ decreased from 1995 to 1999, and decreased again from 1999 to 2005 . In particular, surfaces of $\gamma^{\mathrm{n}}>28.26 \mathrm{~kg}$ $\mathrm{m}^{-3}$ appear to sink progressively, and their intersections with the seabed move southward, between 1995 and 2005. As an example, $\gamma^{\mathrm{n}}=28.30 \mathrm{~kg} \mathrm{~m}^{-3}$ intersected the seabed close to station 47 in 1995 , i.e. around $56.4^{\circ} \mathrm{S}$. In 1999 , this surface intersected the seabed around $56.8^{\circ} \mathrm{S}$ (station 113 ), and in 2005 its intersection was close to $57.4^{\circ} \mathrm{S}$ (station 61). 
Although different station positioning among the years (most notably 2005; Figure 2) makes station-by-station comparisons problematic, further indications of this shift can be obtained by consideration of vertical $\Theta$ and $\mathrm{S}$ profiles from north of the Southern Boundary (Figure 7). The deeper profile depths in 2005 are a reflection of the different station positioning in this year. This complication notwithstanding, the 2005 stations are all warmer and saltier than the 1995 stations by around $0.1^{\circ} \mathrm{C}$ and 0.005 , respectively. The 1999 stations are intermediate, and overlap with both 1995 and 2005. The changes are largely density compensating, such that the $\Theta-\mathrm{S}$ curves from these stations are not significantly different within the accuracy level of the S measurements, except that the densest water present becomes progressively warmer and saltier (not shown).

South of the Southern Boundary there is a somewhat different pattern of change in $\Theta$ within the WSDW (Figure 8). The warming of around $0.05^{\circ} \mathrm{C}$ is present between 1995 and 1999, as discussed previously (Meredith et al., 2001). However, subsequent to this there are no further significant changes between 1999 and 2005, with $\Theta$ values remaining constant on pressure surfaces. The changes in S suggest a possible shift towards saltier WSDW during the sequence of observations (Figure 8, lower panel), but it is small compared with the accuracy of the measurements.

\subsection{Lower Weddell Sea Deep Water variability}

As with WSDW as a whole, there is a reduction in Lower WSDW volume during the sequence of measurements, though it is most notable between 1999 and 2005 for this layer. In 1995, the northern terminus of this water mass (defined as $\gamma^{\mathrm{n}}>28.31 \mathrm{~kg} \mathrm{~m}^{-3}$; Figure 5) was near $57^{\circ} \mathrm{S}$, before moving slightly southward to $\sim 57.25^{\circ} \mathrm{S}$ in 1999 , then farther southward than $58^{\circ} \mathrm{S}$ in 2005 . Within the Lower WSDW, an inflection in the $\Theta-\mathrm{S}$ relation at $\gamma^{\mathrm{n}}=28.31 \mathrm{~kg} \mathrm{~m}^{-3}$ is present in the 1999 
data, with the curves below this level diverting saltier, but is absent from the 1995 and 2005 data (Figure 9). The 1999 curves thus reflect the presence of an additional water mass in the Scotia Sea that was absent in the other years, namely a thin, abyssal layer of comparatively salty Lower WSDW that entered the Scotia Sea via Georgia Passage and possibly other deep gaps in the South Sandwich Island arc (Meredith et al., 2001) (Figure 1). To reach these gaps, this water mass flows northward on the eastern side of the South Sandwich Islands, and its southward and westward entry to the Scotia Sea in 1999 contrasts with the 1995 and 2005 results which indicate that the deepest layer of Lower WSDW had crossed the South Scotia Ridge into the Scotia Sea instead. The $\Theta-\mathrm{S}$ inflection is not evident north of the Southern Boundary in 1999, or south of the Southern Boundary in either of the other years. The 1999 pattern (an inflection south of the Southern Boundary but absent to the north) indicates that the Southern Boundary constitutes a dynamical barrier that plays an important role in controlling the spreading of Lower WSDW into and within the Scotia Sea.

\section{Discussion}

\subsection{Warm Deep Water}

The pattern of $\Theta$ and S variations in WDW in the Scotia Sea is qualitatively consistent with changes observed further south in the Weddell Sea (Fahrbach et al., 2004; Robertson et al., 2002), with warming and salinification up to the mid- and late-1990s followed by a subsequent cooling and freshening. These combined results are strongly suggestive of large-scale changes in the WDW properties in the Weddell Gyre being fed through to the Scotia Sea from upstream following the general circulation, with transit times of roughly a few years between the southern Weddell and Scotia Seas. We note that the $\sim 0.03^{\circ} \mathrm{C}$ and $\sim 0.002$ increases in WDW $\Theta$ and $\mathrm{S}$ values observed during the late 1990s by Fahrbach et al. (2004) (their Figure 5) at the Greenwich Meridian in the 
Weddell Sea are distinctly less than the increases presented here between 1995 and 1999 in the Scotia Sea, and similarly the decrease in $\Theta$ of $\sim 0.05^{\circ} \mathrm{C}$ in the Weddell Sea after the turn of the century is less than the cooling of WDW in the Scotia Sea between 1999 and 2005. However, the Weddell Sea figures are based on basin-wide averages that integrate some complex patterns of warming and cooling (Fahrbach et al., 2004), thus the derived magnitudes of the changes here are expected to be smaller.

An analysis of WDW $\Theta$ changes in "inflowing" and "outflowing” regions of the Weddell Gyre showed WDW $\Theta$ peaking in 1995 in the inflowing region, with more recent values falling by around $0.2^{\circ} \mathrm{C}$ through to 1999 (Robertson et al., 2002). In the outflowing region, a large scatter in WDW $\Theta$ values during the late 1990s made trends in this area hard to identify. The magnitudes of the changes in the WDW values in the Scotia Sea we present here are somewhat less than the longterm ( $\sim 30$ year) warming trends seen in the WDW in the Weddell Sea (Robertson et al., 2002). This latter time series includes several instances of cooling within the general upward trend, and it is unclear whether the recent cooling seen in the Weddell Sea (Fahrbach et al., 2004) is a reversal of the long-term warming trend or another instance of interannual variability against a background of continuing rising temperatures.

With regard to the timing of the peak WDW temperatures in the Weddell and Scotia Seas, the sparse temporal sampling in the latter precludes clear identification of the year of highest temperatures, and thus we cannot be precise concerning a lag between the two basins. Notwithstanding, the connection between WDW properties in the Weddell Sea and Scotia Sea established here implies that continued changes within the Weddell Sea are likely to be reflected as changes in the Scotia Sea in years to come. 


\subsection{Weddell Sea Deep Water}

The changes identified in WSDW in the Scotia Sea are complex, and are summarised here by three main observations:-

1) North of the Southern Boundary, WSDW warmed by around $0.05^{\circ} \mathrm{C}$ between 1995 and 1999, and again by the same amount between 1999 and 2005. A concurrent small salinification (0.005) occurred during the 1995-2005 period. The overall volume of WSDW in this part of the Scotia Sea decreased through the sequence of measurements.

2) South of the Southern Boundary, a comparable level of warming was seen between 1995 and 1999, but there was no significant warming between 1999 and 2005, and no significant salinity change was detected.

3) Within the Lower WSDW layer, changes in circulation were observed, with the densest waters crossing the South Scotia Ridge prior to the 1995 and 2005 sections, but entering the Scotia Sea from its eastern and northeastern flanks prior to 1999.

The observations presented here are best explained by a superposition of a large-scale decadal trend toward higher $\Theta$ and $\mathrm{S}$ in the WSDW of the northern Weddell Sea, and shorter-period (interannual) variability in the export of the densest classes of WSDW to the Scotia Sea (see below). There are two factors that dictate the degrees to which these processes combine to control the observed properties of WSDW in the Scotia Sea, namely the residence times of different classes of WSDW in the basin, and the Southern Boundary's role as a dynamical barrier to the northward spreading of this water mass. 
The mean residence time of a particular class of WSDW in the Scotia Sea is the characteristic period over which the properties of inflowing waters are averaged. This period determines the timescales of variability that the class of WSDW exhibits, and hence indicates the degree to which the variability could be aliased by temporally sparse sampling. Mean residence times (Table 2) are

calculated here by dividing the volume of each WSDW density class within the basin by the volume transport of that density class over the South Scotia Ridge (Heywood et al., 2002; Naveira Garabato et al., 2003). These suggest that the overall WSDW layer in the Scotia Sea is renewed on average every $\sim 5$ years, whereas the Lower WSDW sublayer is flushed more rapidly (around every 3 years). The densest classes of WSDW present in the Scotia Sea (here taken as $\gamma^{\mathrm{n}}>28.35 \mathrm{~kg} \mathrm{~m}^{-3}$ ) are renewed on approximately annual timescales. These are found only south of the Southern Boundary, and the difference in mean residence times for these classes compared with WSDW overall reflects the role of the Southern Boundary as a dynamical barrier to the northward flow of the water mass. The time intervals between the sections used here is comparable to the mean WSDW residence time in the Scotia Sea, but is significantly longer than that of the densest WSDW classes. The variability in denser WSDW properties is thus likely to be aliased within the hydrographic data, whereas the changes in WSDW characteristics north of the Southern Boundary will be well represented.

\subsubsection{Observation (1): continuous warming and salinification of WSDW north of the Southern Boundary}

Knowing the potential extent of aliasing associated with our sampling interval allows us to elucidate which of the two aforementioned processes (a large-scale decadal trend toward higher $\Theta$ and $\mathrm{S}$ in the WSDW of the northern Weddell Sea, and interannual variability in the export of the 
densest classes of WSDW to the Scotia Sea) may explain each of our observed WSDW changes. The decadal trend alone may account for the first observation, because the residence time calculation indicates that WSDW north of Southern Boundary reflects long-term changes in the properties of the WSDW exported from the Weddell Sea.

Several previous studies (Andrié et al., 2003; Coles et al., 1996; Johnson and Doney, 2006; Zenk and Morozov, 2007) have documented a warming at a comparable rate in the WSDW in the South Atlantic as far north as the equator, consistent with the bulk warming of WSDW observed here "upstream" in the Scotia Sea. Decadal warming of the recently ventilated WSDW in the Weddell Sea has not been unambiguously demonstrated, due to the lack of a long time series of observations in the boundary currents directly upstream of the overflow regions at the South Scotia Ridge, but we note here that such a warming would be compatible with the observed decadal-scale warming of WSBW during the 1989-2003 period (Fahrbach et al., 2004). WSBW contains a significant proportion of recently-ventilated shelf waters, and is not directly exported from the Weddell Sea after formation, so changes within this layer are very possibly echoed by changes within the boundary current of WSDW (which contains a higher proportion of recently-ventilated waters than the recirculated WSDW in the central Weddell Sea) that feeds the Scotia Sea.

As with the warming trend, a potential salinification of the recently-ventilated WSDW in the northern Weddell Sea has not been shown unambiguously due to lack of appropriate observations. Robertson et al. (2002) were unable to deduce significant temperature trends for WSDW in the northwestern Weddell Sea due to large scatter in their data, and the same would appear true for salinity (the change of salinity we observe in the Scotia Sea, around 0.005, is small compared to the scatter shown in Figure 9 of Robertson et al. (2002), for example). 


\subsubsection{Observation (2): cessation of warming of WSDW south of the Southern Boundary after 1999}

Mean residence times for WSDW density classes that lie exclusively south of the Southern Boundary are of order 1 year. Therefore, in the southern Scotia Sea, the impact of the decadal-scale warming trend discussed in 5.2.1 is likely to be superposed on interannual variability in the WSDW overflows of the South Scotia Ridge. The mechanisms controlling the variability in these overflows were outlined by Meredith et al. (2001), and are illustrated here schematically (Figure 10). It has been argued that changes in the intensity of the baroclinic component of the Weddell Gyre circulation (most likely associated with changes in integrated wind stress curl over the Weddell Sea) will affect the depth levels at which isopycnals intersect with the South Scotia Ridge, and hence determine the densest class of WSDW able to overflow into the Scotia Sea. A decrease (increase) in the density of the deepest layer of WSDW overflowing the ridge will result in a warming (cooling) on pressure surfaces within the Scotia Sea, but no discernable change on density surfaces. Accompanying S changes will occur, but of a magnitude comparable to the level of detectability. In the context of this conceptual model, a spin-up of the Weddell Gyre between 1995 and 1999 followed by a spin-down prior to 2005 would explain our pattern of observations, with the absence of significant changes south of the Southern Boundary between 1999 and 2005 being due to the opposing effects of interannual variability associated with Weddell Gyre intensity (cooling) and longer-term (decadal) warming.

The extent to which the baroclinicity of the Weddell Gyre varies is poorly known, but there is some evidence that changes of the magnitude required to explain our observations occur. One piece is provided by a 6-year time series of water mass properties collected with moored instrumentation 
immediately upstream of the Orkney Passage (Figure 1) as part of the CORC / ARCHES programme (Visbeck et al., 2001). Although this mooring does not cover the densities that typify the WSDW in the Scotia Sea, and is of shorter duration than the time period covered by our sections, it does provide useful information on the characteristic variability in density on a depth surface exhibited by WSDW in the boundary current of the northern Weddell Sea. The records show that, at three different levels within 500 dbar of the seabed in water depths of around 3059m, pronounced excursions of order $0.005 \mathrm{~kg} \mathrm{~m}^{-3}$ on interannual timescales (around 1-3 years) are prominent within the core of recently ventilated WSDW in the northern Weddell Gyre (Figure 11). The interannual changes in density show a large degree of vertical coherence, consistent with these signals being due to variations in the baroclinicity of the gyre. Hydrographic profiles from this region indicate that a change in density at the mooring of order $0.005 \mathrm{~kg} \mathrm{~m}^{-3}$ corresponds to a change in isopycnal depth of around $100 \mathrm{~m}$, with associated changes of approximately $0.04^{\circ} \mathrm{C}$ in $\Theta$ and 0.002 in $S$ on a pressure surface. These changes are comparable with the variability in $\Theta$ and $S$ observed in the mooring data on interannual timescales (Gordon et al., in preparation, 2007). An interannual perturbation to the baroclinicity of the Weddell Gyre of the magnitude implied by the mooring density data would be sufficient to account for the cessation of the warming of the WSDW south of the Southern Boundary after 1999, whilst resulting in no detectable change in S, in agreement with our observations.

Further evidence for variability in the intensity of the baroclinic Weddell Gyre circulation is given by Martinson and Iannuzzi (2003), who use available hydrographic data from across the gyre to investigate periods of spin-up and spin-down during the last quarter of the $20^{\text {th }}$ century. These authors note significant changes in the gyre's baroclinicity on interannual timescales, which they relate to variations in the phase of the El Niño / Southern Oscillation (ENSO) phenomenon. During 
an El Niño event, the Weddell Gyre was deduced to have spun-up in response to changing winds, and the converse was inferred in response to La Niña. If this relationship applies consistently, as Martinson and Iannuzzi (2003) propose, it might suggest that the apparently anomalous conditions that we observed in the Scotia Sea during 1999 could be connected to the very strong El Niño event that occurred in 1997/98, allowing for a 1-2 year lag for baroclinic spin-up and for the anomalous WSDW that crosses the South Scotia Ridge to spread to the location of our section.

\subsubsection{Observation (3): changes in Lower WSDW circulation}

The change in circulation of Lower WSDW between 1995 and 1999 (Meredith et al., 2001) was seen to subsequently reverse up to 2005 . This pattern of change is consistent with observation 2 (section 5.2.2), and is similarly controlled by variations in the intensity of the Weddell Gyre (see Figure 10). The increase in the density of the deepest WSDW overflowing the South Scotia Ridge associated with the baroclinic spin-down of the Weddell Gyre after 1999 would have precluded the import of the more saline variety of Lower WSDW through Georgia Passage and gaps in the South Sandwich Arc. (A denser outflow through these gaps would act to block the southwestward flow of LWSDW through Georgia Passage into the Scotia Sea abyss). Consequently, 1999 was the only year of the three that showed the influence of the more saline type of Lower WSDW, due to the

reversals in direction of abyssal flow at the northeastern and eastern edges of the Scotia Sea before and after this date.

\section{Conclusions}


A hydrographic section in the eastern Scotia Sea of the Southern Ocean was occupied three times (in April 1995, April 1999 and February 2005), and significant changes in water mass properties were observed. The WDW south of the Southern Boundary warmed and salinified between 1995 and 1999, then cooled and freshened through to 2005. These changes appear to be the consequence of decadal-scale variability in the properties of this water mass upstream in the Weddell Sea, propagated into the Scotia Sea via the Weddell Gyre. The likely influence of the Weddell Polynya on WDW properties has been highlighted (Robertson et al., 2002), and it has been argued that this event may have been triggered by anomalous atmospheric forcing associated with the Southern Hemisphere Annular Mode, and possibly linked to a La Niña event (Gordon et al., 2007). In the context of these studies, our results indicate that climate-scale forcing over the Weddell Sea has impacts that are seen outside the region as the variations induced are propagated northward.

We have reported several changes to the WSDW flowing through the Scotia Sea. North of the Southern Boundary, WSDW warmed and salinified between 1995 and 2005, whereas south of the Southern Boundary the warming was only observed through to 1999. Reversals in the abyssal circulation of the densest classes of WSDW were also observed. The observed WSDW changes are best explained by a superposition of a large-scale decadal trend toward higher $\Theta$ and $\mathrm{S}$ in the WSDW of the northern Weddell Sea, and shorter-period (interannual) variability in the export of the densest classes of WSDW to the Scotia Sea.

We have argued that the interannual variability in the export of WSDW to the Scotia Sea is likely related to changes in the baroclinicity of the Weddell Gyre. These changes may be controlled by cyclonic atmospheric forcing over the Gyre, which has been shown to be modulated by ENSO on interannual timescales (see Martinson and Iannuzzi (2003) and references therein). We conjecture 
that if the interannual modulation of WSDW export by ENSO were also active on longer (decadal) timescales (as implied by the work of Martinson and Iannuzzi, 2003), it may contribute to the WSDW warming observed throughout the South Atlantic. ENSO has undergone long-period changes in recent decades, with a higher preponderance of El Niño events since the 1970s; this would enhance the Weddell Gyre's baroclinicity, and hinder the export of the coldest WSDW.

The WDW and WSDW changes that we observe have potential climatic consequences that transcend regional scales. For example, if the decrease in volume of WSDW in the Scotia Sea between 1995 and 2005 is indicative of a longer-period trend, this will have implications for circulation and climate in much of the world ocean. Warming of the abyssal layer has been reported for recent decades as far north as the equator in the western Atlantic Ocean. This warming is evidence of a major change in the properties of the lower limb of the oceanic overturning circulation, originating in the Weddell Sea and transiting through the Scotia Sea.

To put some of these changes in perspective, climate models suggest that the Earth's energy imbalance is currently about $0.85( \pm 0.15) \mathrm{W} \mathrm{m}^{-2}$, with the oceans absorbing a large fraction of that heat gain (Hansen et al., 2005). The evolution of the heat content of WDW in the eastern Scotia Sea is equivalent to a local heat gain of $\sim 3 \mathrm{~W} \mathrm{~m}^{-2}$ between 1995 and 1999, and a similar local heat loss through to 2005 (c.f. the local heat gain of $4 \mathrm{~W} \mathrm{~m}^{-2}$ implied by the warming of the Weddell Sea between 1977 and 2001; Smedsrud, 2005). In turn, the temperature increase of the WSDW layer in the eastern Scotia Sea between 1995 and 2005 associated with the decadal warming trend yields a local heat gain of $\sim 1 \mathrm{~W} \mathrm{~m}^{-2}$. If the vertical profile of warming rate below $3000 \mathrm{~m}$ between $60^{\circ} \mathrm{S}$ and the equator in the western basins of the South Atlantic for recent decades (Johnson and Doney, 2006) were typical of the entire global ocean abyss, it would account for $\sim 0.2 \mathrm{~W} \mathrm{~m}^{-2}$ of the Earth's 
energy imbalance. Abyssal Pacific warming rates are smaller (Johnson et al., 2007), nonetheless abyssal water temperature variations such as those presented here are not only of high regional importance, but may also contribute significantly to the global heat budget. 


\section{Acknowledgements}

These analyses would not have been possible without the effort of many people at sea and ashore to gather, calibrate, and process the hydrographic section data analyzed here. Phil Mele is thanked for help with the preparation of the figures, and Hartmut Helmer for providing data. Comments by three anonymous reviewers helped to improve the manuscript. The U.K. Natural Environment Research Council (NERC) funded the 1995 and 1999 sections, and supported MPM through British Antarctic Survey funding and ACNG through a NERC Advanced Research Fellowship (NE/C517633/1). The National Oceanic and Atmospheric Administration (NOAA) Office of Oceanic and Atmospheric Research and the NOAA Climate Program Office supported GCJ. NOAA and the National Science Foundation jointly support the U. S. CLIVAR/CO $\mathrm{C}_{2}$ epeat Hydrography Program. This research received funding from the Cooperative Institute for Climate Applications and Research Award NA03OAR4320179 from NOAA. The findings and conclusions in this article are those of the authors and do not necessarily represent the views of NERC or NOAA. This is Pacific Marine Environmental Laboratory contribution 3106 and Lamont-Doherty Earth Observatory contribution 7103. 


\section{References}

Andrié, C. et al., 2003. Variability of AABW properties in the equatorial channel at 35W. Geophysical Research Letters, 30(8007): 10.1029/2002GL015766.

Arhan, M., Heywood, K.J. and B.A.King, 1999. The deep waters from the Southern Ocean at the entry to the Argentine Basin. Deep-Sea Research, 46: 475-499.

Boehme, L., Thorpe, S.E., Meredith, M.P., Biuw, M. and Fedak, M., 2007. The dynamic ACC frontal system around South Georgia, Southern Ocean. Journal of Marine Systems: submitted.

Coles, V.J., McCartney, M.S., Olson, D.B. and Smethie, W.M., 1996. Changes in the Antarctic Bottom Water properties in the western South Atlantic in the late 1980s. Journal of Geophysical Research, 101: 8957-8970.

Fahrbach, E., Hoppema, M., Rohardt, G., Schröder, M. and Wisotzki, A., 2004. Decadal-scale variations of water mass properties in the deep Weddell Sea. Ocean Dynamics, 54(77-91).

Foster, T.D. and Carmack, E.C., 1976. Frontal zone mixing and Antarctic Bottom Water formation in the southern Weddell Sea. Deep-Sea Research, 23: 301-317.

Gill, A.E., 1973. Circulation and bottom water production in the Weddell Sea. Deep-Sea Research, 20: 111-140.

Gille, S.T., 2002. Warming of the Southern Ocean Since the 1950s. Science, 295: 1275-1277.

Gordon, A.L., 1966. Potential temperature, oxygen and circulation of bottom water in the Southern Ocean. Deep-Sea Research, 13, 1125-1138.

Gordon, A.L., 1998. Western Weddell Sea Thermohaline Stratification. In: S.S. Jacobs and R.F. Weiss (Editors), Ocean, Ice and Atmosphere: Interactions at the Antarctic Continental Margin. American Geophysical Union, Washington D.C., pp. 215-240. 
Gordon, A.L., Visbeck, M. and Comiso, J., 2007. A possible link between the Weddell Polynya and the Southern Annular Mode. Journal of Climate, 20: 2558-2571.

Gordon, A.L., Visbeck, M. and Huber, B., 2001. Export of Weddell Sea Deep and Bottom Water. Journal of Geophysical Research, 106(C5): 9005-9017.

Hansen, J. et al., 2005. Earth's energy balance: Confirmation and implications. Science, 308: 14311435.

Heywood, K.J. and King, B.A., 2002. Water masses and baroclinic transports in the South Atlantic and Southern oceans. Journal of Marine Research, 60(639-676).

Heywood, K.J., Naveira-Garabato, A.C. and Stevens, D.P., 2002. High mixing rates in the abyssal Southern Ocean. Nature, 415: 1011-1014.

Jackett, D.R. and McDougall, T.J., 1997. A neutral density variable for the world's oceans. Journal of Physical Oceanography, 27: 237-263.

Johnson, G.C. and Doney, S.C., 2006. Recent western South Atlantic bottom water warming. Geophysical Research Letters, 33(L14614): 10.1029/2006GL026769.

Johnson, G.C., Mecking, S., Sloyan, B.M. and Wijffels, S.E., 2007. Recent bottom water warming in the Pacific Ocean. Journal of Climate, 20: 5365-5375.

Locarnini, R.A., Whitworth, T. and Nowlin, W.D., 1993. The Importance of the Scotia Sea on the Outflow of Weddell Sea Deep Water. Journal of Marine Research, 51(1): 135-153.

Martinson, D.G. and Iannuzzi, R.A., 2003. Spatial/temporal patterns in Weddell gyre characteristics and their relationship to global climate. Journal of Geophysical Research, 108(C4): 10.1029/2000JC000538.

Meredith, M.P., A.C. Naveira Garabato, D.P. Stevens, K.J. Heywood and Sanders, R.J., 2001. Deep and Bottom Waters of the Eastern Scotia Sea: Rapid Changes in Properties and Circulation. Journal of Physical Oceanography, 31(8): 2157-2168. 
Meredith, M.P. et al., 2000. On the sources of Weddell Gyre Antarctic Bottom Water. Journal of Geophysical Research, 105(C1): 1093-1104.

Naveira Garabato, A.C., Heywood, K.J. and Stevens, D.P., 2002a. Modification and pathways of Southern Ocean Deep Waters in the Scotia Sea. Deep-Sea Research I, 49: 681-705.

Naveira Garabato, A.C., McDonagh, E.L., Stevens, D.P., Heywood, K.J. and Sanders, R.J., $2002 b$.

On the export of Antarctic Bottom Water from the Weddell Sea. Deep-Sea Research II, 49: 4715-4742.

Naveira Garabato, A.C., Stevens, D.P. and Heywood, K.J., 2003. Water mass conversion, fluxes and mixing in the Scotia Sea diagnosed by an inverse model. Journal of Physical Oceanography, 33: 2565-2587.

Nowlin, W.D. Jr. and W. Zenk, 1988. Westward bottom currents along the margin of the South Shetland Island Arc. Deep-Sea Research, 35, 269-301.

Orsi, A.H., Nowlin, W.D. and Whitworth, T., 1993. On the Circulation and Stratification of the Weddell Gyre. Deep-Sea Research I, 40(1): 169-203.

Orsi, A.H., Whitworth, T. and Nowlin, W.D., 1995. On the Meridional Extent and Fronts of the Antarctic Circumpolar Current. Deep-Sea Research I, 42(5): 641-673.

Robertson, R., Visbeck, M., Gordon, A.L. and Fahrbach, E., 2002. Long-term temperature trends in the deep waters of the Weddell Sea. Deep-Sea Research II, 49: 4791-4806.

Sievers, H.A. and Nowlin, W.D., 1984. The stratification and water masses at Drake Passage. Journal of Geophysical Research, 89(C6): 10,489-10,514.

Smedsrud, L.H., 2005. Warming of the deep water in the Weddell Sea along the Greenwich meridian: 1977-2001. Deep-Sea Research I, 52: 241-258.

Smith, W.H.F. and Sandwell, D.T., 1997. Global Sea Floor Topography from Satellite Altimetry and Ship Depth Soundings. Science, 277: 1956-1962. 
Visbeck, M. et al., 2001. The CORC/ARCHES Observing System for Weddell Sea Deep and Bottom Water Variability. CLIVAR Exchanges, 6(4): 23-25.

Whitworth, T., Nowlin, W.D., Orsi, A.H., Locarnini, R.A. and Smith, S.G., 1994. Weddell Sea Shelf Water in the Bransfield Strait and Weddell-Scotia Confluence. Deep-Sea Research I, 41(4): 629-641.

Zenk, W. and Morozov, E., 2007. Decadal warming of the coldest Antarctic Bottom Water flow through the Vema Channel. Geophysical Research Letters, 34(L14607): 10.1029/2007GL030340. 


\section{Figure Captions}

Figure 1. Location of repeat section used here (red line) and position of the CORC/ARCHES M2 mooring (black dot) immediately southeast of the South Orkneys (SO), with bathymetry (Smith and Sandwell, 1997) color shaded in meters. Antarctic Circumpolar Current fronts marked schematically: Subantarctic Front (SAF), Polar Front (PF) and Southern ACC Front (SACCF) positions from Boehme et al. (2007), and Southern Boundary (SB) from Orsi et al. (1995). Marked topographic features include $\mathrm{SG}=$ South Georgia, $\mathrm{SO}=$ South Orkneys, $\mathrm{OP}=$ Orkney Passage, GP $=$ Georgia Passage, and SSI $=$ South Sandwich Islands. The primary route of spreading of Weddell Sea Deep Water through and around the Scotia Sea is shown schematically (yellow solid arrows), with the intermittent inflow of its densest component through GP also marked (yellow dashed arrow).

Figure 2. Locations of CTD stations used here (See Fig. 1 for broader context). Data were collected during (a) 1995, (b) 1999, and (c) 2005. Background shading is depth (m).

Figure 3. Vertical-meridional sections of potential temperature $\left({ }^{\circ} \mathrm{C}\right)$ from hydrographic sections (Figure 1 shows location) occupied in (a) 1995, (b) 1999 and (c) 2005. Individual station locations marked along the upper horizontal axis (see also Figure 2). Locations of the Southern Boundary (SB) and Southern ACC Front (SACCF) are also marked.

Figure 4. Vertical-meridional salinity (PSS-78) sections. Details follow Figure 3. Non-uniform contour interval used. 
Figure 5. Vertical-meridional neutral density $\left(\gamma^{\mathrm{n}} ; \mathrm{kg} / \mathrm{m}^{3}\right.$; Jackett and McDougall, 1997) sections. Details follow Figure 3. Note the change in contour interval for $\gamma^{\mathrm{n}}>28.28 \mathrm{~kg} / \mathrm{m}^{3}$.

Figure 6. Potential temperature $\left({ }^{\circ} \mathrm{C}\right.$; upper panel) and salinity (lower panel) versus pressure south of the Southern Boundary for 1995 (black), 1999 (red) and 2005 (green). Profiles have been smoothed with a 20-dbar Butterworth filter. Station locations are shown in Figure 2.

Figure 7. Potential temperature $\left({ }^{\circ} \mathrm{C}\right.$; upper panel) and salinity (lower panel) versus pressure for stations in the latitude range 56 to $57^{\circ} \mathrm{S}$, north of the Southern Boundary and the narrow eddy feature seen in 1995 and 1999, for 1995 (black), 1999 (red), and 2005 (green). Profiles have been smoothed with a 20-dbar Butterworth filter. Station locations are shown in Figure 2.

Figure 8. Potential temperature $\left({ }^{\circ} \mathrm{C}\right.$; upper panel) and salinity (lower panel) versus pressure for stations south of the Southern Boundary in 1995 (black), 1999 (red), and 2005 (green). Profiles have been smoothed with a 20-dbar Butterworth filter. Station positions are shown in Figure 2.

Figure 9. Potential temperature - salinity curves for 1995 (upper panel), 1999 (middle panel) and 2005 (lower panel) for stations south of the Southern Boundary. An inflection at $\gamma^{\mathrm{n}}=28.31 \mathrm{~kg} \mathrm{~m}^{-3}$, the Lower Weddell Sea Deep Water upper boundary, visible in 1999, is absent in 1995 and 2005.

Figure 10. Schematic of the impact of changing atmospheric cyclonic forcing on Weddell Gyre intensity, and the consequences for the export of Weddell Sea Deep Water (WSDW) across the South Scotia Ridge (SSR) and the abyssal circulation of Lower WSDW. The inset (adapted from Coles et al., 1996) shows schematically the steepening (A) or slumping (B) of isopycnal surfaces in 
the Weddell Sea in response to Gyre spin-up/down, and the consequent change in the density of the deepest WSDW exported across the SSR to the Scotia Sea. The top panel illustrates case (A), where a stronger Weddell Gyre leads to less dense (warmer) WSDW crossing the SSR, and Lower WSDW entering the Scotia Sea through Georgia Passage and environs at the northeastern edge of the basin. The lower panel illustrates case (B), where a weaker Weddell Gyre leads to denser (colder) WSDW crossing the SSR, and the absence of an inflow of Lower WSDW through Georgia Passage and environs.

Figure 11. Time series of potential density $\left(\sigma_{0}\right.$, top $)$ and neutral density $\left(\gamma^{\mathrm{n}}\right.$, bottom) at the CORC/ARCHES M2 mooring site, color-coded to indicate pressure separations of instruments from the seabed $($ red $=345$ dbar; black 1999-2001 = 15 dbar; black 2001-2003 = 31 dbar; blue $=$ 478 dbar). Moorings deployed in 3059-m water depth (see Figure 1). Pronounced excursions in density $\left(\sim 0.005 \mathrm{~kg} \mathrm{~m}^{-3}\right)$ on timescales of around 1-3 years exhibit significant vertical coherence. 


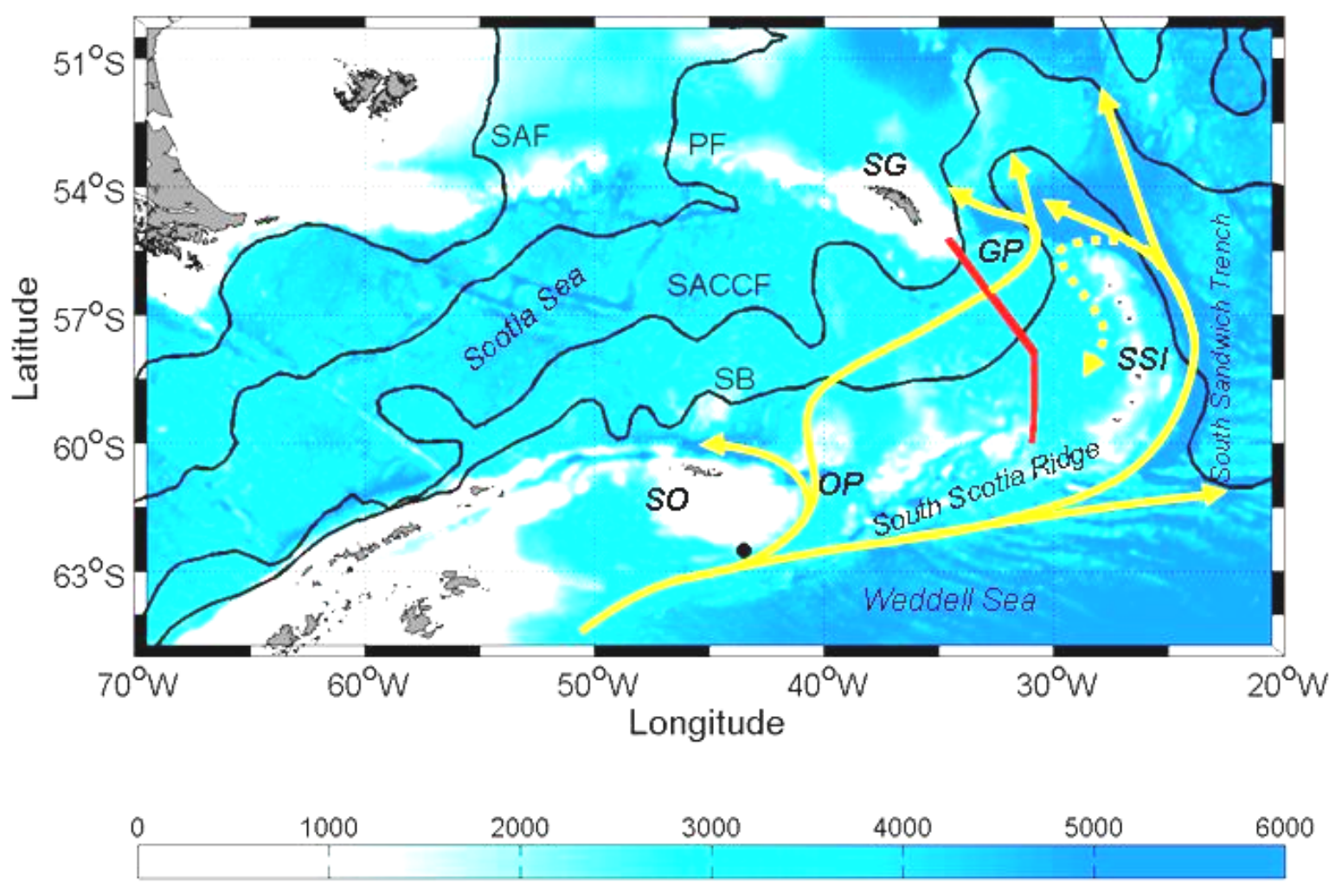

Figure 1. Location of repeat section used here (red line) and position of the CORC/ARCHES M2 mooring (black dot) immediately southeast of the South Orkneys (SO), with bathymetry (Smith and Sandwell, 1997) color shaded in meters. Antarctic Circumpolar Current fronts marked schematically: Subantarctic Front (SAF), Polar Front (PF) and Southern ACC Front (SACCF) positions from Boehme et al. (2007), and Southern Boundary (SB) from Orsi et al. (1995). Marked topographic features include $\mathrm{SG}=$ South Georgia, $\mathrm{SO}=$ South Orkneys, $\mathrm{OP}=$ Orkney Passage, GP $=$ Georgia Passage, and SSI $=$ South Sandwich Islands. The primary route of spreading of Weddell Sea Deep Water through and around the Scotia Sea is shown schematically (yellow solid arrows), with the intermittent inflow of its densest component through GP also marked (yellow dashed arrow). 

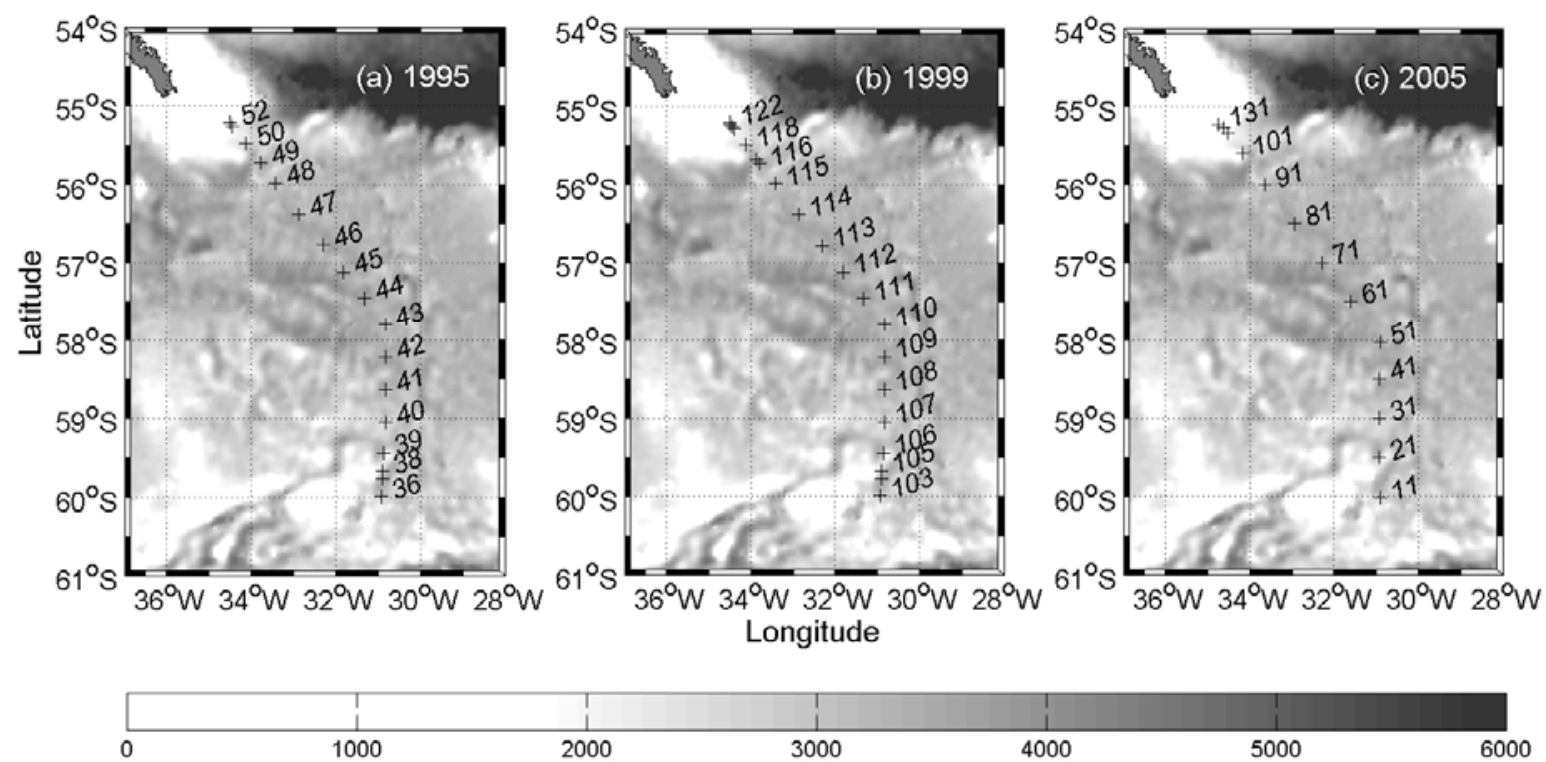

Figure 2. Locations of CTD stations used here (See Fig. 1 for broader context). Data were collected during (a) 1995, (b) 1999, and (c) 2005. Background shading is depth (m). 

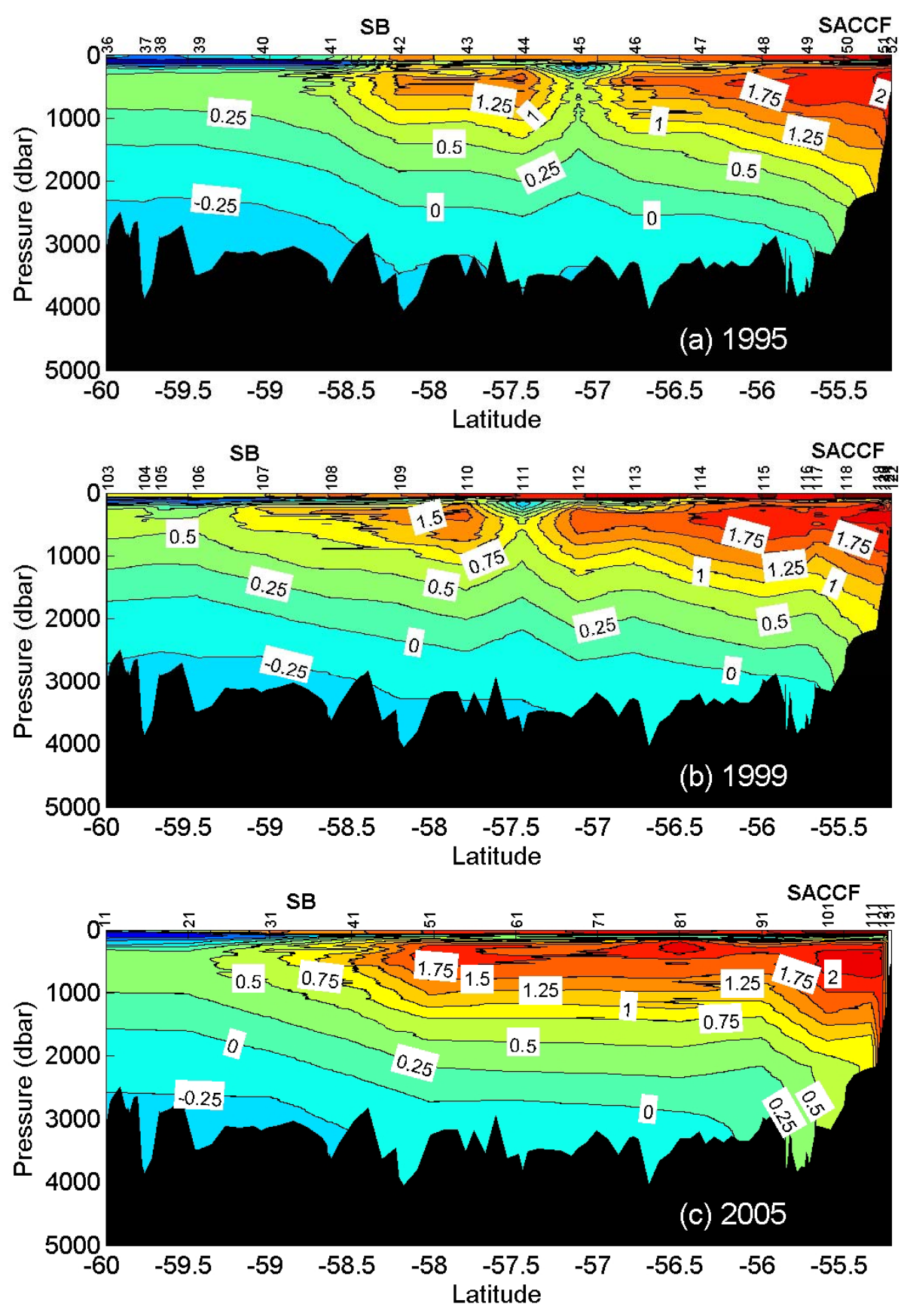

Figure 3. Vertical-meridional sections of potential temperature $\left({ }^{\circ} \mathrm{C}\right)$ from hydrographic sections (Figure 1 shows location) occupied in (a) 1995, (b) 1999 and (c) 2005. Individual station locations marked along the upper horizontal axis (see also Figure 2). Locations of the Southern Boundary (SB) and Southern ACC Front (SACCF) are also marked. 

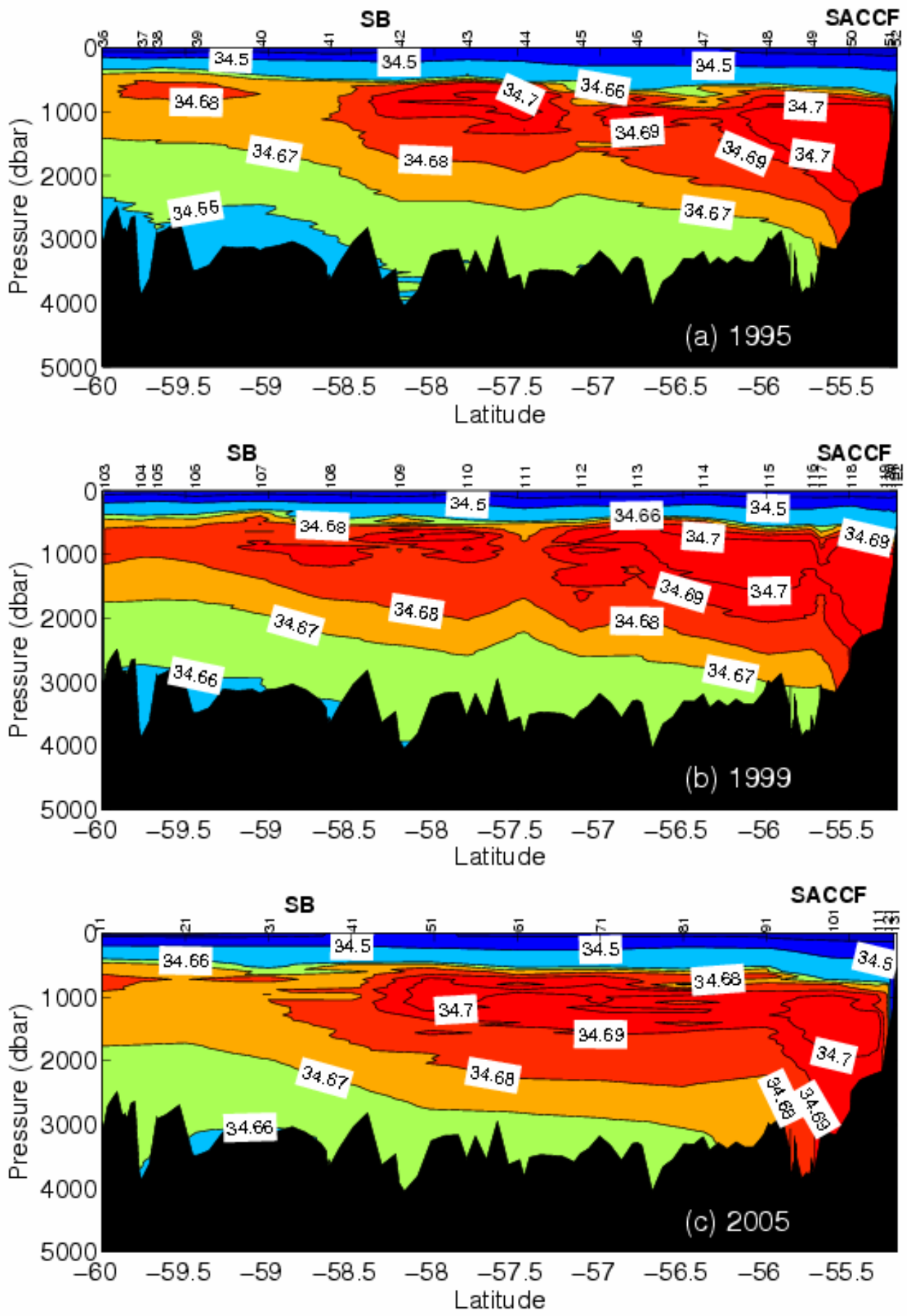

Figure 4. Vertical-meridional salinity (PSS-78) sections. Details follow Figure 3. Non-uniform contour interval used. 

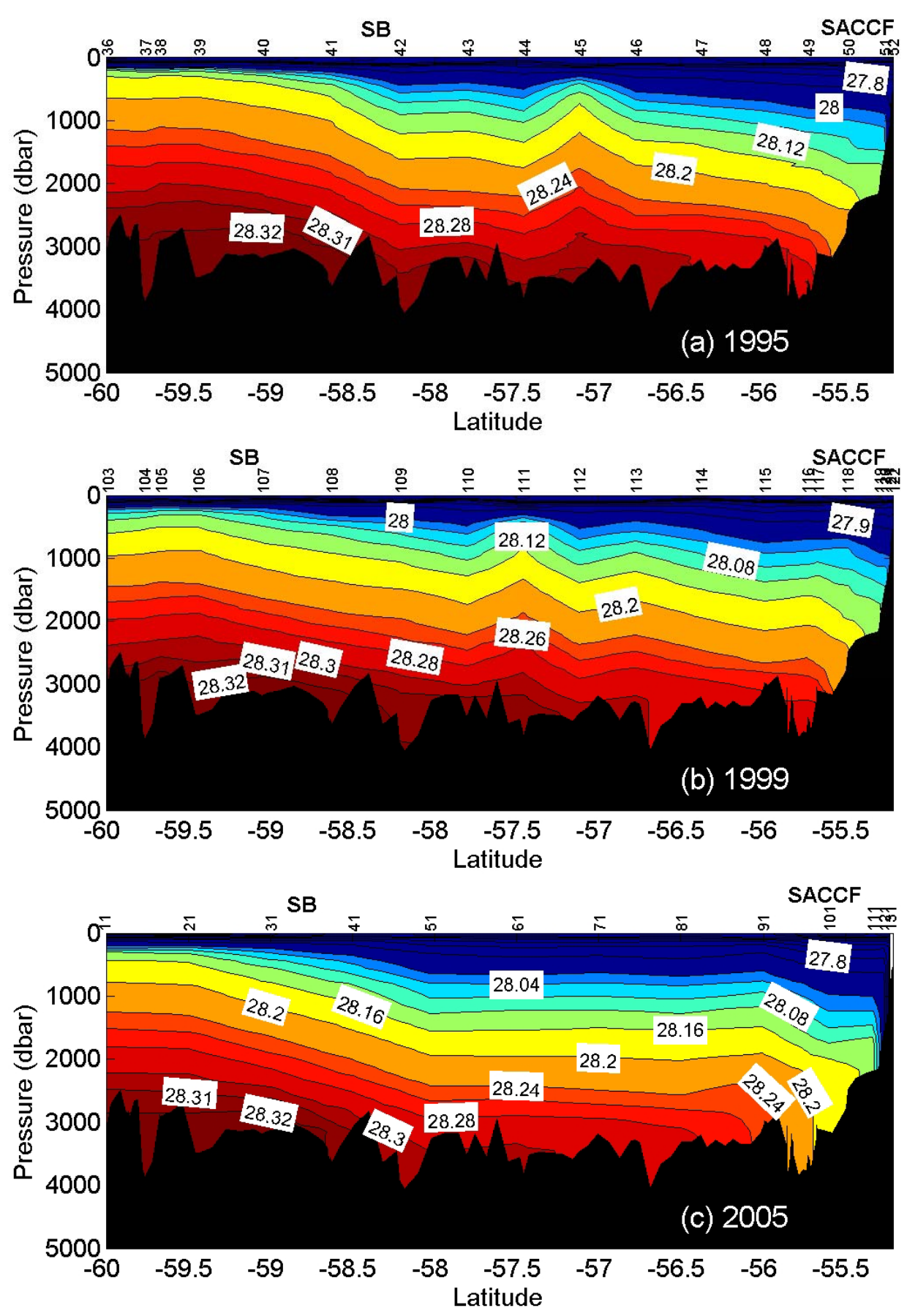

Figure 5. Vertical-meridional neutral density $\left(\gamma^{\mathrm{n}} ; \mathrm{kg} / \mathrm{m}^{3} ;\right.$ Jackett and McDougall, 1997) sections. Details follow Figure 3. Note the change in contour interval for $\gamma^{\mathrm{n}}>28.28 \mathrm{~kg} / \mathrm{m}^{3}$. 

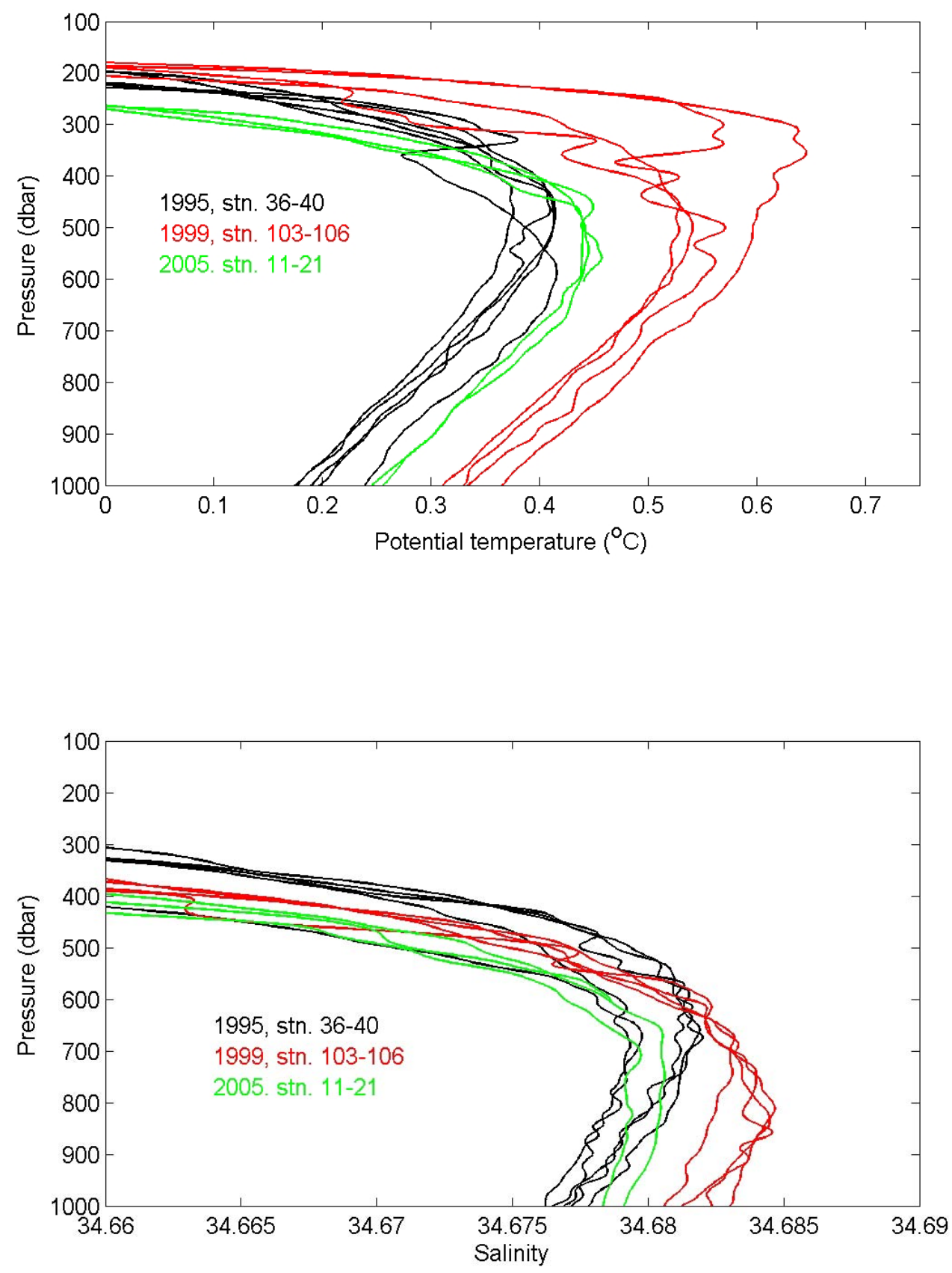

Figure 6. Potential temperature $\left({ }^{\circ} \mathrm{C}\right.$; upper panel) and salinity (lower panel) versus pressure south of the Southern Boundary for 1995 (black), 1999 (red) and 2005 (green). Profiles have been smoothed with a 20-dbar Butterworth filter. Station locations are shown in Figure 2. 

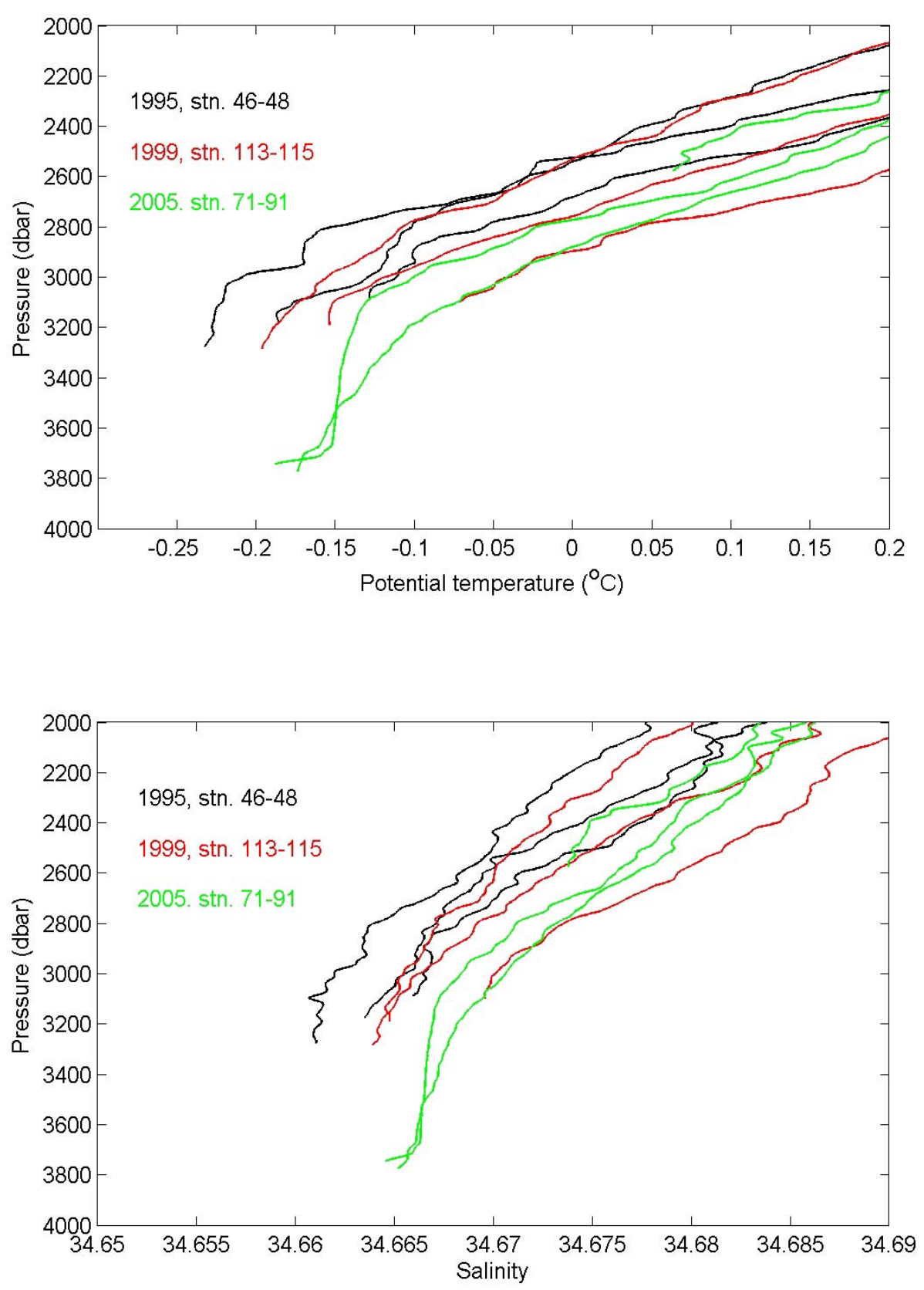

Figure 7. Potential temperature $\left({ }^{\circ} \mathrm{C}\right.$; upper panel) and salinity (lower panel) versus pressure for stations in the latitude range 56 to $57^{\circ} \mathrm{S}$, north of the Southern Boundary and the narrow eddy feature seen in 1995 and 1999, for 1995 (black), 1999 (red), and 2005 (green). Profiles have been smoothed with a 20-dbar Butterworth filter. Station locations are shown in Figure 2. 

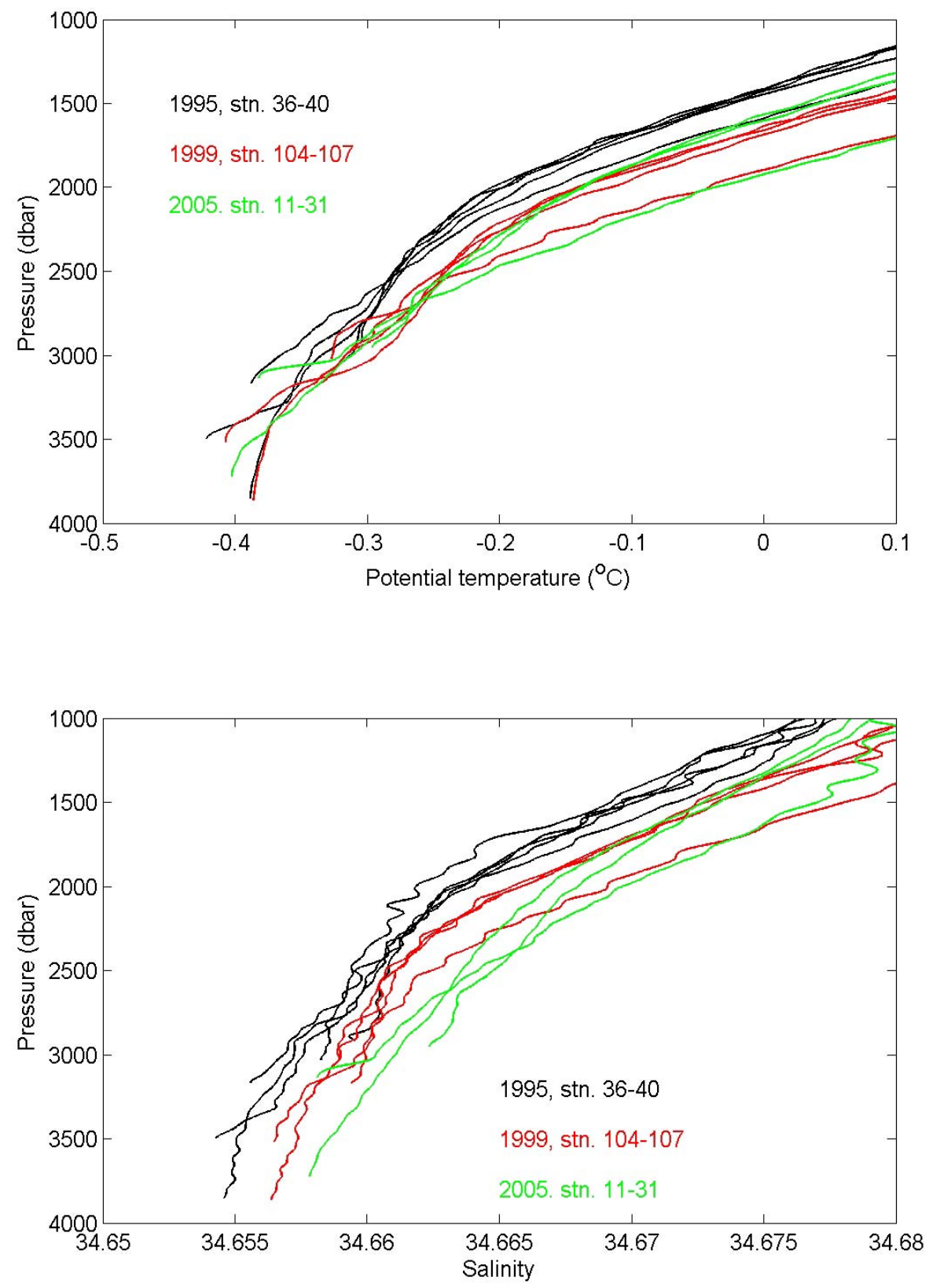

Figure 8. Potential temperature $\left({ }^{\circ} \mathrm{C}\right.$; upper panel) and salinity (lower panel) versus pressure for stations south of the Southern Boundary in 1995 (black), 1999 (red), and 2005 (green). Profiles have been smoothed with a 20-dbar Butterworth filter. Station positions are shown in Figure 2. 

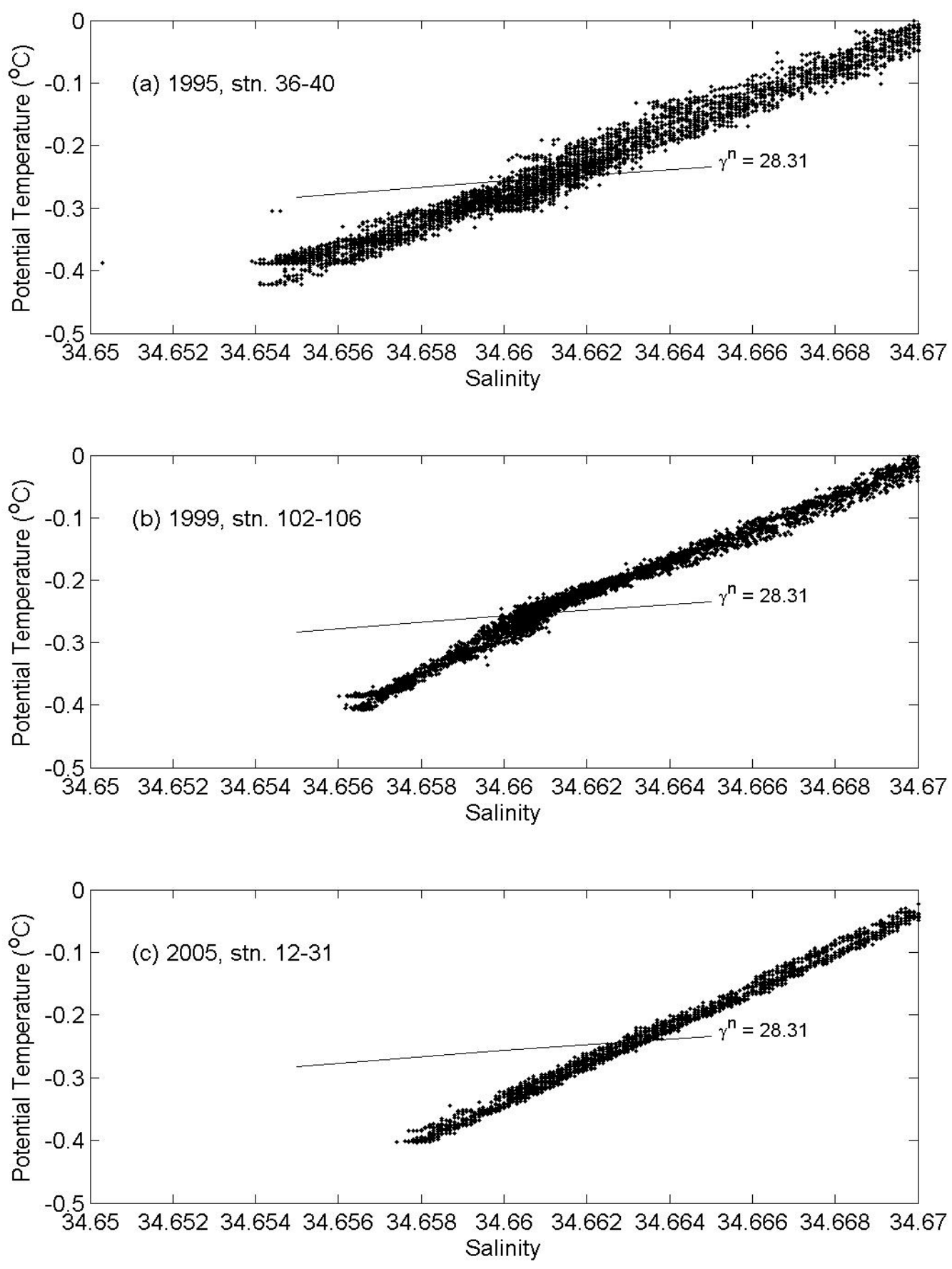

Figure 9. Potential temperature - salinity curves for 1995 (upper panel), 1999 (middle panel) and 2005 (lower panel) for stations south of the Southern Boundary. An inflection at $\gamma^{\mathrm{n}}=28.31 \mathrm{~kg} \mathrm{~m}^{-3}$, the Lower Weddell Sea Deep Water upper boundary, visible in 1999, is absent in 1995 and 2005. 


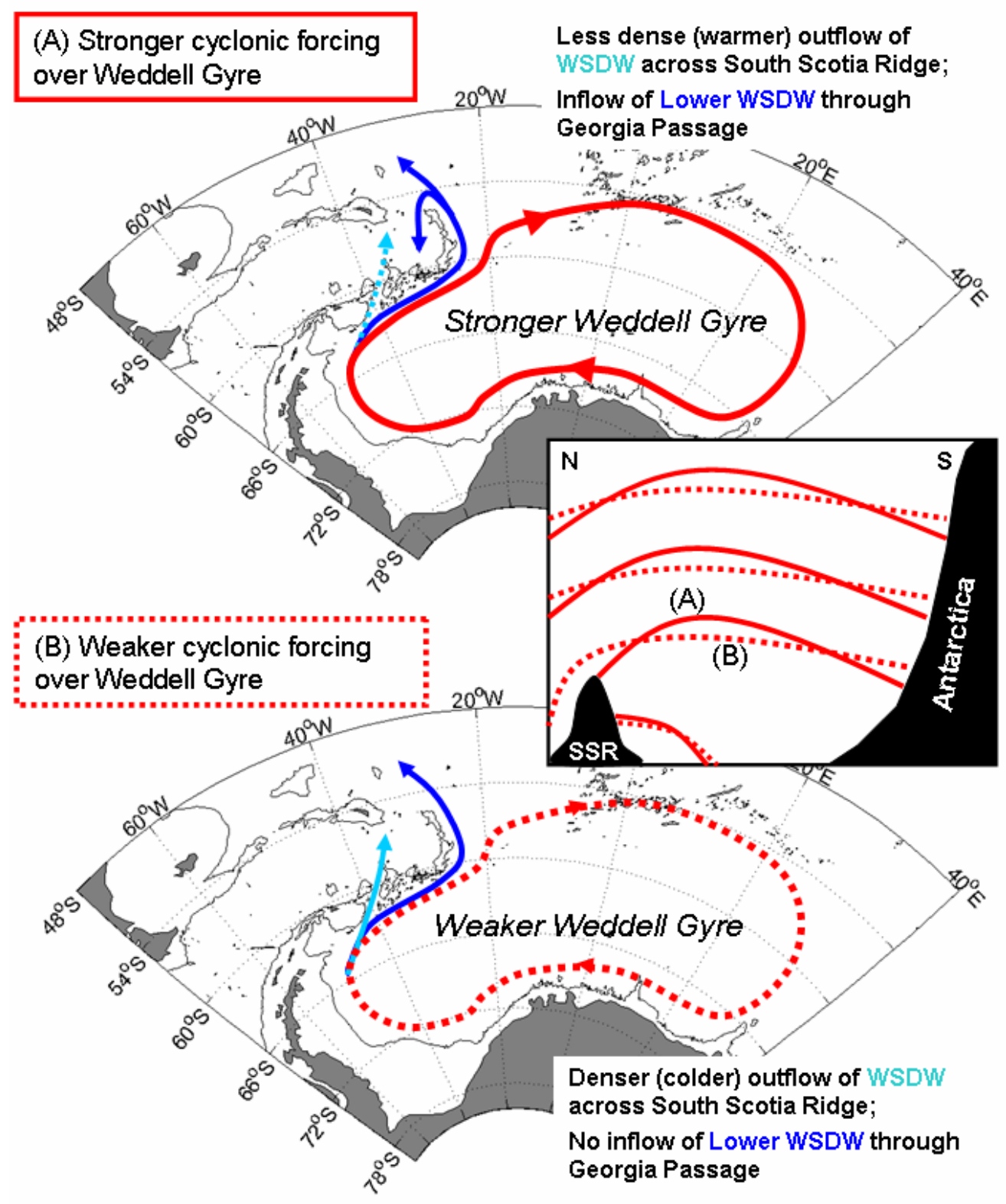

Figure 10. Schematic of the impact of changing atmospheric cyclonic forcing on Weddell Gyre intensity, and the consequences for the export of Weddell Sea Deep Water (WSDW) across the South Scotia Ridge (SSR) and the abyssal circulation of Lower WSDW. The inset (adapted from Coles et al., 1996) shows schematically the steepening (A) or slumping (B) of isopycnal surfaces in the Weddell Sea in response to Gyre spin-up/down, and the consequent change in the density of the deepest WSDW exported across the SSR to the Scotia Sea. The top panel illustrates case (A), where a stronger Weddell Gyre leads to less dense (warmer) WSDW crossing the SSR, and Lower WSDW entering the Scotia Sea through Georgia Passage and environs at the northeastern edge of the basin. The lower panel illustrates case (B), where a weaker Weddell Gyre leads to denser (colder) WSDW crossing the SSR, and the absence of an inflow of Lower WSDW through Georgia Passage and environs. 


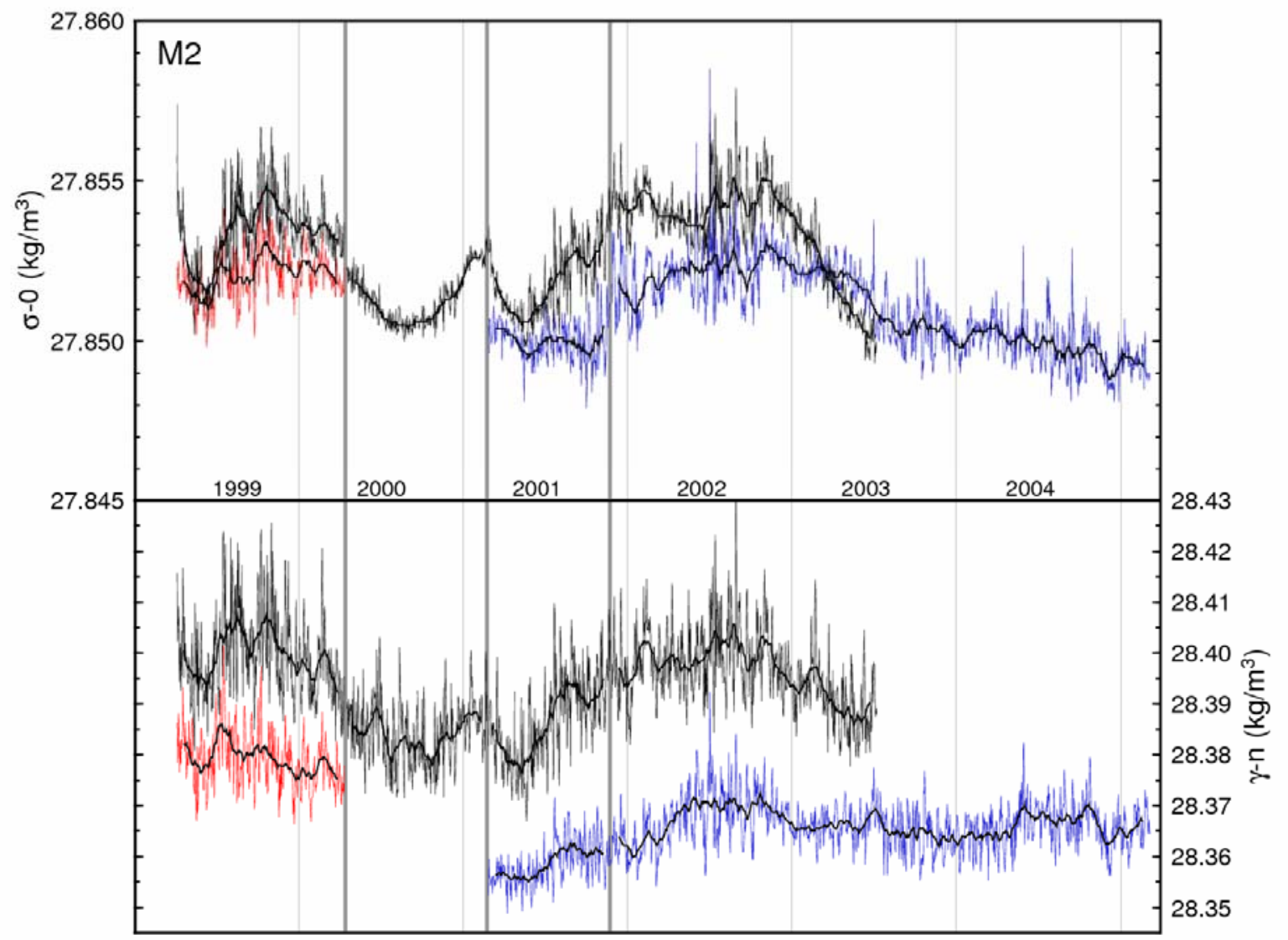

Figure 11. Time series of potential density ( $\sigma_{0}$, top) and neutral density ( $\gamma^{\mathrm{n}}$, bottom) at the CORC/ARCHES M2 mooring site, color-coded to indicate pressure separations of instruments from the seabed (red = 345 dbar; black 1999-2001 = 15 dbar; black 2001-2003 = 31 dbar; blue $=$ 478 dbar). Moorings deployed in 3059-m water depth (see Figure 1). Pronounced excursions in density $\left(\sim 0.005 \mathrm{~kg} \mathrm{~m}^{-3}\right)$ on timescales of around $1-3$ years exhibit significant vertical coherence. 


\begin{tabular}{c|c|c} 
Water mass & Abbreviation & Identifiers \\
\hline Warm Deep Water & WDW & $\begin{array}{c}\Theta_{\max } \text { near } 500 \mathrm{~m} \\
\mathrm{~S}_{\max } \text { near } 800 \mathrm{~m} \\
\gamma^{\mathrm{n}}<28.20 \text { in the ACC }\end{array}$ \\
\hline $\begin{array}{c}\text { Weddell Sea Deep } \\
\text { Water }\end{array}$ & WSDW & $28.26<\gamma^{\mathrm{n}}<28.40$ \\
\hline $\begin{array}{c}\text { Upper Weddell Sea } \\
\text { Deep Water }\end{array}$ & Upper WSDW & $28.26<\gamma^{\mathrm{n}}<28.31$ \\
\hline $\begin{array}{c}\text { Lower Weddell Sea } \\
\text { Deep Water }\end{array}$ & Lower WSDW & $28.31<\gamma^{\mathrm{n}}<28.40$ \\
\hline $\begin{array}{c}\text { Weddell Sea Bottom } \\
\text { Water }\end{array}$ & WSBW & $\gamma^{\mathrm{n}}>28.40$
\end{tabular}

Table 1. Scotia Sea and Weddell Sea water masses of Southern Ocean origin discussed in this paper. $\gamma^{\mathrm{n}}$ is the neutral density variable of Jackett and McDougall (1997), with units $\mathrm{kg} \mathrm{m}^{-3}$. 


\begin{tabular}{c|c|c|c|c}
$\begin{array}{c}\gamma^{\mathrm{n}} \text { of upper } \\
\text { water mass } \\
\text { boundary }[\mathrm{kg} \\
\left.\mathrm{m}^{-3}\right]\end{array}$ & $\begin{array}{c}\text { Area in Scotia } \\
\text { Sea }\left[\mathrm{m}^{2}\right]\end{array}$ & $\begin{array}{c}\text { Volume in } \\
\text { Scotia Sea }\left[\mathrm{m}^{3}\right]\end{array}$ & $\begin{array}{c}\text { Inflowing } \\
\text { volume } \\
\text { transport [Sv] }\end{array}$ & $\begin{array}{c}\text { Mean residence } \\
\text { time [yr] }\end{array}$ \\
\hline 28.26 & $\begin{array}{c}(1.1 \pm 0.2) \times \\
10^{12}\end{array}$ & $\begin{array}{c}(8.7 \pm 1.9) \times \\
10^{14}\end{array}$ & $5.9 \pm 1.7$ & $4.7 \pm 1.7$ \\
\hline 28.31 & $\begin{array}{c}(7.0 \pm 1.5) \times \\
10^{11}\end{array}$ & $\begin{array}{c}(3.1 \pm 0.8) \times \\
10^{14}\end{array}$ & $3.5 \pm 1.2$ & $2.8 \pm 1.2$ \\
\hline 28.35 & $\begin{array}{c}(1.1 \pm 0.4) \times \\
10^{11}\end{array}$ & $\begin{array}{c}(5.2 \pm 2.4) \times \\
10^{13}\end{array}$ & $1.7 \pm 0.5$ & $1.0 \pm 0.5$
\end{tabular}

Table 2. Area, volume, inflowing volume transport and mean residence time of three overlapping density classes of WSDW with varying upper boundaries. Areas and volumes estimated by objective mapping of density profiles obtained from historical atlas data, the three sections used in this study, and six occupations of a transect across Drake Passage. Method described more extensively in Heywood et al. (2002). Uncertainties in the areas and volumes estimated ad hoc by varying objective mapping parameters. Volume transports over the South Scotia Ridge estimated from the box inverse model solution of Naveira Garabato et al. (2003). Errors correspond to one standard deviation uncertainties from the inverse model. Mean residence times calculated by dividing volumes by volume transports. 